\title{
THE EMPIRICAL RELATIONSHIP OF ROA AND NPM ON THE PERFORMANCE OF CONSUMER GOODS COMPANIES IN INDONESIA: A GENERAL REVIEW OF BUILDING UP ECONOMY
}

\author{
Dewi Wuisan \\ \{dewi.wuisan@uph.edu\} \\ Universitas Pelita Harapan, Tangerang,
}

\begin{abstract}
Understanding the company's performance is the desire of the company and useful for investors. A consumer goods company continues to survive in every economic situation because it is a consumption business needed by every society regardless of the country's economic situation. Looking at the company's performance in generating profits and knowing how to predict return on asset (ROA) for the coming year helps the company to see its growth in challenges of future economic. There were 6 companies involved in this study: ADES, ALTO, CEKA, DLTA, INDF and MYOR with 54 data from 2009 to 2017, taken from Jakarta Stock Exchange. There were 2 equations used: ROA (independent variables were net profit margin (NPM), R_MKT, return on equity (ROE), revenue and the dummy variable was type to distinguish food and beverage companies), and NPM (independent variable: ROA, current ratio and earnings per share (EPS)). The results show that ROA and NPM had a simultaneous relationship where they influence each other. Therefore, the increase in current ratio would result in an increase in NPM so as to increase the company performance described by the increase in ROA. In the calculation using a dummy variable (type), it was found that it would reduce the influence of each independent variable to dependent variable although the decrease was not significant. Meanwhile, the calculation by using ARIMA was the goal of predicting ROA in the years to come to see the company development.
\end{abstract}

Keywords: Consumer Goods, 5 Classical Assumptions, ROA, NPM, ARIMA

\section{Introduction}

Consumer goods is an industrial company that has become one of the important sectors. It helps the economic growth of a country in consumption sector and is also considered attractive for investment despite the rise in world crude oil prices which causes an unstable economic condition in Indonesia. They are industries that continue to survive through changes and challenges of any economic condition because they meet important daily needs. Therefore, people will continue to consume their goods. These companies are supporting sectors of economic growth because it is developing quite rapidly despite of the monetary crisis and act as one of the saviors of the economy.

Go-public consumer goods companies play an important role in the economy. 
It is expected to maintain and improve its performance to survive in times of crisis and increasingly fierce competition. These companies have the ability to improve the country's economy, so that they require relatively large funds with fixed costs and stable sales. It is mainly because their goods are crucially needed by everyone.

\subsection{Growth of Consumer Goods Companies}

The performance of consumer goods companies showed that their sales growth and net profit were 10\% -13\% throughout 2017. Maulida [1] stated that it would depend on commodity prices. He added that if the commodity prices in 2017 were stable and improved, then it would be excellent in the long run. In addition, for a medium term of 2-5 years, there were three bonuses that could support the economy in Indonesia such as global economic growth, improved commodity prices and middle-income growth. Indonesia had an economic growth of $4.7 \%$ when the commodity prices were very weak. He also argued that when the economy was not assisted by commodities, the economic growth would still be quite good as there was a domestic consumption as the economic motor. In 2016, the performance of the consumer goods index had grown $14.79 \%$ on an annual basis.

For this reason, the measure of company performance is the return on assets (ROA). The financial performance variables used are net profit management (NPM), R_MKT, return on equity (ROE), revenue, current ratio and earning per share (EPS).

\subsection{Company Performance}

According to Hanafi [2], understanding the company performance can be done by considering several indicators the company has in obtaining profitability shown from several financial ratios, such as ROA, ROE, NPM, and EPS which measure the ability of companies to produce net income based on the level of assets certain.

Van Horne and Wachowicz [3] suggested that profitability is the ability of companies to generate profits in certain periods. Profit is often a measure of company performance. When the company has high profits, it means it has a good performance and vice versa. The company's profit is not only an indicator of the company's ability to meet obligations for its investors, but also an element in creating corporate value that shows the company's prospects in the future.

The company financial performance is one of the factors considered by investors in investing. One financial ratio that can be used as an indicator in measuring a company's financial performance is the profitability ratio Information on financial performance is useful for predicting a company's capacity to generate cash flow from existing resources. In addition, the information is also useful in the formulation of considerations about the effectiveness of the company in utilizing additional resources. 


\subsection{Analysis of Company Growth}

According to Van Horne and Wachowicz [3], a more specific measurement of profitability ratios related to sales is to use net profit margin. It refers to a measure of a company's profitability from sales after calculating all costs and income taxes.

According to Hatta [4], companies with high sales and profit growth rates tend to distribute dividends more consistently than companies with low sales and growth rates. Mathematically, the size of the company (size) can be formulated as follows:

$$
\text { Sales Growth }=\frac{\text { Net Sales }(t)-\text { Net Sales }(t-1)}{\text { Net Sales }(t-1)}
$$

According to Mursidah [5], ROE is a very important ratio for the company owner (The Common Stockholder), because this ratio shows the return rate generated by management from the capital provided by the company owner. It shows the benefits that will be enjoyed by the shareholders. Its growth shows that the company's prospects are getting better because there are potential increased profits earned. Therefore, it will increase investor confidence and facilitate the company's management to attract capital in the form of shares.

Current ratio (CR) is a ratio that shows how current liabilities are covered by assets that will be converted into cash in the near future. It is an indicator of liquidity ratios most commonly used to describe a company's ability to meet its short-term obligations that are past due. According to Weygandt [6], CR is a widely used measurement to evaluate a company's liquidity and ability to pay short-term debt.

According to Aminatuzzharan [7], CR Is a liquidity ratio illustrating the ability of companies to meet short-term obligations that are past due. It is an indicator of the liquidity ratio - a ratio between current assets and current liabilities owned by the company. It measures the assets owned by the company in the current debt of Aminatuzzahra [7].

Examined the Indonesia Stock Exchange in the period of 2007 to 2009 in the consumer goods industry and found that ROA and NPM partially had no significant effect on returns. While the EPS, debt equity ratio (DER) and price to book value $(\mathrm{PBV})$ variables had a significant effect on stock returns.

\section{Methods}

There were 6 consumer goods companies listed on the Indonesia Stock Exchange in 2009-2017 involved in this study which consisted of 54 data. They also published complete financial statements.

According to Baltagi [8], in estimating parameters of the model with panel data, there are three techniques: 1) Common effect model; 2) Fixed effect model; 3) Random effect model.

There are also three tests for panel data estimation in a study by Gujarati [9]: 1) Chow test; 2) Hausman test; 3) Lagrange multiplier (LM) test 
In a technical perspective, it was more relevant when the authors ignored the common effect model as the data was a panel data which had different characteristics of individuals and time. While the common effect model only combined cross section and time-series data as a unity without considering the differences.

\section{Results \& Discussions}

In the panel data regression, after selecting the model, testing the classical assumptions and the feasibility of the model, the last step was to interpret the model developed. Interpretations made on the regression coefficient included two things: value and direction. The value referred to the coefficient values in the regression equation and the direction indicated the direction of the relationship which could be either positive or negative.

A positive direction showed that the direction was in line where each increase in value on the independent variable would have an impact on increasing the value on the dependent variable.

In contrast, a negative direction showed the opposite effect where each increase in value on the independent variable would have an impact on the decrease in the value on the dependent variable.

By choosing ADES company, a simultaneous and ARIMA calculation would be seen. The following is the equation model:

ROA $=\alpha+$ NPM + R_MKT + ROE + REVENUE + TYPE

After a regression was done, then a classical assumption test was performed.

A simultaneous model and ARIMA calculation were applied with the following equation factors influencing the ROA and NPM in the consumer goods companies in the period of 2009 to 2017, the following equation is made:

(1) $\mathrm{ROA}=\alpha+\mathrm{NPM}+\mathrm{R}$ MKT + ROE + REVENUE + TIPE

(2) $\mathbf{N P M}=\boldsymbol{\beta}+\mathbf{R O A}+\mathbf{C R}+\mathbf{E P S}$

ROA : return on assets

NPM : net profit margin

R_MKT : a change in the years of Sales

ROE : return on equity

Revenue: a company revenue from 2008-2017

CR : current ratio

EPS : earning per share

TYPE : a dummy variable where 1 is a beverage company \& 0 is a food company

Table 1. Comparison of results of data with and without using LOC as a dummy variable

\begin{tabular}{|c|c|c|c|c|}
\hline Variable & $\begin{array}{c}\text { With Dummy } \\
\text { Variable } \\
\text { Prob. }\end{array}$ & $\begin{array}{c}\text { Without Dummy } \\
\text { Variable) } \\
\text { Prob. }\end{array}$ & $\begin{array}{c}\text { With Dummy } \\
\text { Variable }\end{array}$ & $\begin{array}{c}\text { Without } \\
\text { Dummy } \\
\text { Variable }\end{array}$ \\
\hline C & 0.2836 & 0.4724 & & \\
\hline
\end{tabular}




\begin{tabular}{|c|l|l|l|l|}
\hline NPM & 0.0003 & 0.1616 & & \\
\hline R_MKT & 0.7796 & 0.8850 & & \\
\hline ROE & 0.0000 & 0.0000 & & \\
\hline REVENUE & 0.4586 & 0.5515 & & \\
\hline TYPE & 0.0087 & & & \\
\hline R-squared & & & 0.858384 & 0.830585 \\
\hline Adjusted R-quared & & & 0.842649 & 0.815854 \\
\hline
\end{tabular}

Source: Created using e Views

From Table 1, it can be seen that there is a difference on the value of Prob. which gets smaller when there is TYPE as a dummy variable. It is not clear whether the independent variable significantly influenced the dependent variable or not. For example, the NPM value, when the dummy variable is used, shows that the Prob. is smaller than the one without the dummy variable. Therefore, it could be concluded that TYPE, as a dummy variable on the consumer goods companies (foods and beverages type), did not make an increase in the NPM which influenced the company performance represented by ROA.

The existence of TYPE as a dummy variable would reduce the effect of each independent variable represented by NPM, R_MKT, ROE, and REVENUE to the dependent variable of ROA. It is shown by a decreasing R-squared from 0.858384 to 0.830585 and adjusted R-squared from 0.842649 to 0.815854 although the decrease is not significant.

The Following Regression Is For The Second Equation:

\section{$\mathbf{N P M}=\boldsymbol{\beta}+\mathbf{R O A}+\mathbf{C R}+\mathbf{E P S}$}

After understanding that the company performance was influenced by NPM and $\mathrm{CR}$, the companies and investors should calculate the prediction of the ROA of each company for years to come.

As a sample, the following is ARIMA calculation for ADES company as the same calculation method was only represented by one sample.

Table 2. Result Of ARIMA of ADES

\begin{tabular}{|l|r|r|r|}
\hline ARIMA & AR(1) & MA(1) & AR(1)MA(1) \\
\hline Akaike info criterion & 6.894660 & 6.894897 & 7.116757 \\
\hline Schwarz criterion & 6.960401 & 6.960638 & 7.204412 \\
\hline
\end{tabular}

Source: Created using e Views

The data shows the value of Akaike info and Schwatz criteria on the calculation of AR (1), MA (1) and AR (1) MA (1). The smallest value is AR (1) and it was used to predict.

ROA_ADES from 2018-2020 based on the calculation with AR (1):

Table 3. Result of ROA_ADES from 2018-2020 based on the calculation with AR (1)

\begin{tabular}{|r|r|}
\hline Year & ROA \\
\hline 2009 & $\mathrm{NA}$ \\
\hline 2010 & 9.928037 \\
\hline
\end{tabular}




\begin{tabular}{|l|l|}
\hline 2011 & 10.05159 \\
\hline 2012 & 10.06769 \\
\hline 2013 & 10.06979 \\
\hline 2014 & 10.07006 \\
\hline 2015 & 10.07010 \\
\hline 2016 & 10.07010 \\
\hline 2017 & 10.07010 \\
\hline 2018 & 10.07010 \\
\hline 2019 & 10.07010 \\
\hline 2020 & 10.07010 \\
\hline
\end{tabular}

Source: Created using e Views

\section{Conclusions}

From the results of the regression and panel data, it was concluded that the ROA and NPM had a simultaneous relationship where they influenced each other.

In the ROA data, the NPM has Prob. value of 0.0003 which is $<0.05$ and it shows a positive effect. Next, it was found that the NPM influenced CR where it has Prob. value of 0.0002 which is $<0.05$. Therefore, it could be concluded that an increase in current ratio might result in an increase in NPM so as to increase the company performance represented by an increase in ROA.

In the calculation using a dummy variable, it was found that TYPE reduced the effect of each independent variable represented by NPM, R_MKT, ROE, and REVENUE to dependent variable of ROA, characterized by a decreasing R-squared from 0.858384 to 0.830585 and a decreasing adjusted R-squared from 0.842649 to 0.815854 although the decrease is not significant.

The calculation with ARIMA aims to understand how to predict the ROA in the coming years using ARIMA. In the discussion section, only one example was taken of how to calculate ARIMA for one company (ADES) because the same calculation method was only represented by one sample. The results of calculations with AMIRA shows that the ROA_ADES C AR(1) equation was obtained because it has the smallest Akaike info and Schwatz criteria values.

Therefore, by predicting the ROA, it is expected that companies can predict their performance growth and it can be used as a reference for the company.

\section{References}

[1] Market.bisnis.com. 2017. Emiten Consumers Good Diprediksi Tumbuh 10\%-13\%. https://market.bisnis.com/read/20170126/7/623213/emiten-consumers-good-diprediksi-tumbuh10-13, date accesed: July 202019

[2] Hanafi, M. Mamduh dan Abdul Halim. "Manajemen Keuangan”, PT.BPFE, Yogyakarta, 2004. [3] Van Horne, James and Wachowicz, JM. 2005. Fundamentals of Financial: Management Prinsip-Prinsip Manajemen Keuangan. Penerjemah: Dewi Fitriasari dan Deny Arnos Kwary. Penerbit Salemba Empat: Jakarta. Indonesia. 
[4] Hatta, Atika J, (2002), Faktor-faktor yang Mempengaruhi Kebijakan Dividen: Investifasi Pengaruh Teori Stakeholder. JAAI. Vol.6. No.2. Desember. 2002

[5] Mursidah, Nurfadilah. "Analisis Pengaruh Earning Per Share, Debt to Equity Ratio dan Return on Equity terhadap Harga Saham PT.UNILEVER INDONESIA Tbk", Jurnal STIE Muhamadyah Samarinda, Vol.12 No.1, 2011.

[6]Weygandt J.J., \& Donald E. Kieso. (2008). Pengantar Akuntansi. Jakarta: Salemba Empat. [7] Aminatuzzahra. 2010. Analisis Pengaruh Current Ratio, Debt To Equity Ratio, Total Asset Turnover, Net Profit Margin Terhadap ROE. Skripsi Fakultas Ekonomi Universitas Diponegoro.

[8]Baltagi, B. H. 2008. Econometrics (4th ed). Verlag Berlin Heidelberg: Springer [9]Gujarati, D. N. 2004. Basic Econometrics (4th ed). New York: The McGraw-Hill Companies 